Indonesian Journal of Medicine (2018), 3(1): 22-26

https://doi.org/10.26911/theijmed.2018.03.01.03

\title{
Hepcidin and Feritin Levels in Obese Pregnant Women and Normal Body Weight before Pregnancy
}

\author{
Hadiyatur Rahma ${ }^{1,2)}$, Sarma N Lumbanraja3), Zulfikar Lubis4) \\ 1)Department of Pharmacology, Faculty of Medicine, Islam Sumatera Utara University, Medan \\ 2)Biomedicine Science, Medical School, Graduate School, Universitas Sumatera Utara \\ 3)Department of Obstetrics and Gynecology, H.Adam Malik Hospital, Medan \\ 4)Department of Clinical Pathology, H.Adam Malik Hospital, Medan
}

\begin{abstract}
Background:Obesity is associated with a decrease in iron status, possibly it is an increase in hepcidin, an inflammatory protein that reduces iron absorption. Hepcidin is associated with iron homeostasis and inflammation. This study aims to determine differences in levels of hepcidin and ferritin of obesity pregnant women and normal weight before pregnancy.

Subjects and Method: This was an analytic observational study with a case control design. A total of 62 pregnant women was selected by consecutive technique sampling and divided into 2 groups, namely obesity and normal weight before pregnancy. The study was conducted at RSIA Badrul Aini Medan and at RSUP H.Adam Malik Medan from September to December 2016. The dependent variable of this study was the weight before pregnancy. The independent variable washepcidin levels examined by ELISA method, ferritin content with Immunochemiluminescent method. The data analysis employed Mann Whitney's different test.

Results: Median of hepcidin level in obese pregnant women before pregnancy was higher than pregnant mother with normal weight of $7.08 \mathrm{ng} / \mathrm{mL}$ (2.14 to 78.18). There was no difference in hepcidin level in both groups $(\mathrm{p}=0.578)$. Median ferritin levels in obese pregnant women were higher than the normal weight of $20.57 \mu \mathrm{g} / \mathrm{L}$ (3.66 to 102.25). There was no difference of ferritin levels in both groups $(\mathrm{p}=0.598)$.

Conclusion: This study showed no difference in hepcidin levels and ferritin levels in obese pregnant women and normal weight before pregnancy.
\end{abstract}

Keywords: Feritin, hepcidin, obesity before pregnancy, normal body weight before pregnancy

\section{Correspondence:}

Hadiyatur Rahma. Department of Pharmacology, Faculty of Medicine, Islam Sumatera Utara University, Medan. Email: rahmahadiyatur@gmail.com.

\section{BACKGROUND}

$\overline{\text { Obesity in various countries increases each }}$ year. Increased obesity in women in particular is of serious concern as it becomes a problem when obesity continues to develop in a reproductive age. Based on research conducted in London, there was $27.5 \%$ pregnant women with overweight and $10.9 \%$ of obese pregnant women (Sebire et al., 2001). Pregnant women with obesity are at risk 3.84 times with anemia (Salah et al., 2009). Obesity is a mild chronic inflamemation associated with the expression and release of proinflammatory cytokines, including inter- leukin 6 (IL-6) and tumor necrosis factor $\alpha$ (TNF $\alpha$ ) (Greenberg and Obin, 2006). IL-6 induces the transducer and activator of transcription (STAT3) signals binding to the hepcidin promoter which ultimately increases the expression of hepcidin (Papanikolaou et al., 2005). Hepcidin is known as a systemic iron regulation center and host defense mediator in infections and inflammation.

Several studies have shown hepcidin association, chronic inflammation and low iron status in obesity. Hepcidin expression in obesity was higher and $68 \%$ had iron deficiency, Tsat<25\%, anemia (24\%) (Bekri et 
al., 2006). Hepcidin in HuH17 human hepatoma cells in are upregulated by leptin via the JAK / STAT3 pathway (Chung et al., 2007). Obese women are twice as likely to have iron deficiency compared to those with normal weight (Cepeda et al., 2011). The serum hepcidin and CRP levels were higher in obesity than those who are in normal weight and lower iron status (Tussing-Humphreys et al., 2011).

Maternal hepcidin level, CRP in obese women is higher than normal weight. BMI correlates with maternal hepcidin. Maternal BMI is negatively correlated with iron serum in cord blood. The hepcidin cord blood rate did not differ between obese mothers with normal weight (Dao et al., 2013). Iron deposits in pregnancy with lower obesity and hepcidin are higher than in normal-weight pregnancies. Obesity in pregnancy is at risk of iron deficiency compared to pregnancy with normal BMI (Valdes et al., 2015).

This study aims to compare hepcidin and ferritin levels of pregnant women who are obese and of normal weight before pregnancy.

\section{SUBJECTS AND METHOD \\ 1. Study Design \\ This was an analytic observational study with a case control design. The study was con- ducted at RSIA Badrul Aini, Medan. The sampling examination was conducted at $\mathrm{H}$. Adam Malik hospital, Medan, from Sep- tember to December 2016.}

\section{Population and samples}

The sampling was done by a consecutive sampling technique. Subjects in this study were 31 pregnant women with a history of obesity weight and 31 pregnant women with a normal weight history before pregnancy that met the criteria of pregnant women with obesity (BMI before pregnancy> 25kg / m2 and normal weight (BMI before pregnancy 18.5 to $22.9 \mathrm{~kg} / \mathrm{m} 2), \mathrm{Hb}>10.5 \mathrm{~g} / \mathrm{dL}$, 2nd and 3rd trimester pregnancies, body temperature within normal limits Exclusion criteria included pregnant women who lose weight before pregnancy, leukocytosis and neutrophilia, history of diabetes in pregnancy, pregnancy The subject of the study voluntarily signed the informed consent form and received approval from the Ethics Commission of the Faculty of Medicine, University of North Sumatra.

\section{Study Instrument}

The data characteristic of subjects included age, gestational age, height, body weight before pregnancy, and parity obtained through interview and questionnaires. Serum hepcidin levels were examined by ELISA and ferritin was examined by Immunochemiluminescent method. The data analysis employed Mann Whitney test.

\section{RESULTS}

The subjects who participated in this study were 62 people who were overall at the age of 30-31 years old. Mostly in the 2nd trimester (67.7\%). Overall, food intake consumed by pregnant women was quite good and nutritious although consuming milk and iron tablets was quite low (Table 1). The hepcidin value was not normally distributed, therefore, the median value acted as a centralized and maximum-size measure as a measure of data distribution. The median value of hepcidin levels in pregnant women who were obese before pregnancy was higher than the normal weight which was $7.08 \mathrm{ng} / \mathrm{mL}$ (2.14 up to 78.18). There was no difference in hepcidin levels in both groups $(\mathrm{p}=0.578)$. Median ferritin levels in obese pregnant women were higher than the normal weight of $20.57 \mu \mathrm{g} / \mathrm{L}$ (3.66 to 102.25). There was no difference in ferritin levels in both groups $(p=0.598)$. 
Table 1. The Characteristics of Study Subjects in the Obese Group and Normal Weight Group Before Pregnancy.

\begin{tabular}{|c|c|c|c|c|}
\hline \multirow{2}{*}{ Characteristics } & \multicolumn{2}{|c|}{ Obese $(\mathbf{n}=31)$} & \multicolumn{2}{|c|}{ Normal Birth Weight $(n=31)$} \\
\hline & $\mathbf{N}$ & $\%$ & $\mathbf{n}$ & $\%$ \\
\hline Age (Years) & 31 & & 30 & \\
\hline \multicolumn{5}{|l|}{ Age of pregnancy } \\
\hline - 2nd Trimester & 20 & 64.5 & 22 & 71 \\
\hline - 3rd Trimester & 11 & $35 \cdot 5$ & 9 & 19 \\
\hline \multicolumn{5}{|l|}{ Parity } \\
\hline - Nulipara & 6 & 19.4 & 8 & 25.8 \\
\hline - Primipara & 11 & $35 \cdot 5$ & 11 & $35 \cdot 5$ \\
\hline - Multipara & 14 & 45.1 & 12 & 38.7 \\
\hline \multicolumn{5}{|l|}{ Diet } \\
\hline - Rice & 31 & 100 & 31 & 100 \\
\hline - Fish, Meat & 24 & 77 & 29 & 93 \\
\hline - Vegetables and Fruits & 27 & 87 & 25 & 81 \\
\hline - Milk & 15 & 48 & 11 & 35 \\
\hline - Consumption of Iron & 18 & & & 48 \\
\hline Tablets & & 58 & 15 & \\
\hline
\end{tabular}

Table 2.Laboratory Results of the Study Subjects with a History of Obesity and Normal Weight Before Pregnancy

\begin{tabular}{lccccccc}
\hline Variable & N & Mean & Median & SD & Min & Max & p \\
\hline Hepcidin & & & & & & & \\
(ng/mL) & 62 & 9.71 & 6.37 & 14.20 & 1.01 & 90.18 & 0.578 \\
- Obese & 31 & 9.83 & 7.08 & 13.21 & 2.14 & 78.18 & \\
- Normal & 31 & 9.58 & 6.24 & 15.35 & 1.01 & 90.18 & \\
Feritin $(\mu \mathrm{g} / \mathrm{L})$ & 62 & 28.40 & 16.30 & 27.16 & 2.90 & 102.25 & 0.598 \\
- Obese & 31 & 28.04 & 20.57 & 26.69 & 3.66 & 102.25 & \\
- Normal & 31 & 28.76 & 15.00 & 28.07 & 2.90 & 98.15 & \\
\hline
\end{tabular}

\section{DISCUSSIONS}

In this study, hepcidin levels between obese pregnant women and weight before pregnancy did not show any significant difference. This result was in contrary with a study by Dao et al., (2013) which stated thathepcidin and CRP levels in pregnant women who were obese before pregnancy were higher than pregnant women with normal weight $(\mathrm{p}<0.01)$. Pregnancy with a history of obesity degree 2 or BMI $>35$ $\mathrm{kg} / \mathrm{m} 2$ lead to increased CRP, proinflammatory cytokines (IL-6, TNF $\alpha$ ) and low iron levels on the baby's cord. When ferritin was low, there was an enhancement in IL-6, however, this happened if BMI > 35 $\mathrm{kg} / \mathrm{m}^{2}$ (Dosch et al., 2016). Hedengran et al., (2015) also stated that there was no correlation between hepcidin and iron parameters ( $\mathrm{Hb}$, ferritin, transferrin, transferrin saturation) and inflammatory marker. Shculze et al., (2008) stated that ferritin and maternal hepcidin were moderately correlated. Complicated and uncomplicated pregnant women, hepcidin was not correlated with ferritin, CRP and IL-6 in each trimester of pregnancy (Simavli et al., 2013). In this study, inflammation that occurred in the group of pregnant women who were obese before 
pregnancy was not too heavy. Obesity was a mild degree of chronic inflammation that did not greatly increased the response/ expression of hepcidin. These different results may be influenced by various things such as nutritional factors (diet) due to obesity in the western populations which generally occurred in low socioeconomic, in contrary with the developing countries, and possibly genetic factors. During pregnancy, there was suppression of hepcidin as an effort/body response to maximize iron availability to maintain hemoglobin levels (Weiss and Goodnough, 2005). Ferritin levels also did not show differences due to the level of ferritin influenced by nutrients intake which have no difference in both groups. Beside as a marker of iron status, ferritin also acted as acute phase protein in both groups, the inflammation was not heavy because it was on a healthy subject. Body iron levels were strongly influenced by nutritional intake.

This study concluded that there was no difference in hepcidin levels in obese pregnant women and normal weight before pregnancy and there was no difference in ferritin levels in obese pregnant women and normal weight before pregnancy.

\begin{tabular}{l}
\hline REFERENCES \\
\hline Ahmed SR,Ellah MAA,Mohamed OA, Eid \\
HM (2009). Prepregnancy Obesity \\
and Pregnancy Outcome. Internatio- \\
nal Journal of Health Sciences, \\
Qassim University, 3(2). \\
Bekri S, Gual P, Anty R (2006). Increased \\
adipose tissue expression of hepcidin \\
in severe obesity is independent from \\
diabetes and NASH. Gastroentero- \\
logy.131:788-796.
\end{tabular}

Cepeda-Lopez AC, Osendarp SJ, MelseBoonstra A, Aeberli I, GonzalezSalazar F, Feskens E, Villalpando S, Zimmermann MB (2011). Sharply higher rates of iron deficiency in obese Mexican women and children are predicted by obesity-related inflammation rather than by differences in dietary iron intake. Am J Clin Nutr.93:975-83.

Chung B, Matak P, McKie AT, Sharp P (2007). Leptin increases the expression of the iron regulatory hormone hepcidin in $\mathrm{HuH}_{7}$ human hepatoma cells. J Nutr.137:2366-70

Dao MC, Sen S, Iyer C, Klebenov D, Meydani SN (2013).Obesity during pregnancy and fetal iron status: is Hepcidin the link?. J Perinatol. 33:177-81.

Dosch NC, Guslits EF, Weber MB, Murray ES, Ha B, Coe CL, Auger AP (2016). Materal Obesity Affects Inflamatory and Iron Indices in Umbilical Cord Blood. 172:20-28

Greenberg AS, Obin MS (2006). Obesity and the role of adipose tissue in inflammation and metabolism. Am J Clin Nutr. 83:S461-S465

Hedengran K, , Nelson, Andersen, Stender, Pal B. Szecsi (2015): Hepcidin levels are low during pregnancy and increase around delivery in women without iron deficiency - a prospective cohort study, The Journal of Maternal-Fetal \& Neonatal Medicine. http://dx.doi.org/10.3109/14767058. 2015.1052396.

Papanikolaou G, Tzilianos M, Christakis JI (2005). Hepcidin in iron overload disorders. Blood, 105:4103-5.

Sebire NJ, Jolly M, Harris JP, Wadsworth J, Joffe M, Beard RW, et al. Maternal obesity and pregnancy outcome: a study of 287,213 pregnan ` 1 cies in London. Int $\mathrm{J}$ Obes Relat Metab Disord 2001;25:1175-82

Schulze KJ, Christian P, Ruczinski I, Ray AL, Nath A, Wu LSF, Semba RD 
Indonesian Journal of Medicine (2018), 3(1): 22-26

https://doi.org/10.26911/theijmed.2018.03.01.03

(2008). Hepcidin and iron status among pregnant woman in Bangladesh. Journal of Clinical Nutrition, 17 (13): 451-456.

Simavli S, Derbent AU, Keskin EA, Gumus II, Uysal S, Turhan N (2015). Do the first, second and third trimester maternal serum hepcidin concentration clarify obstetric complications?. J Matern Fetal Neonatal Med, 28(7).

Tussing-Humphreys L, Pini M, Ponemone V, Braunschweig C, Fantuzzi G (2011). Suppressed cytokine production in whole blood cultures may be related to iron status and hepcidin and is partially corrected following weight reduction in morbidly obese premenopausal women. Cytokine. 53: 201-6.

Valdes L, Campoy C, Hayes H, Florido J, Rusanova I, Miranda MT, McArdle HJ (2015). The impact of maternal obesity on iron status, placental transferrin receptor expression and hepcidin expression in human pregnancy. International Journal of obesity. Doi: 10.1038/ijo.2-15.3.

Weiss G, Goodnough LT (2005). Anemia of chronic disease. N Eng J Med, 352: 1011-23. 